\title{
Geopoéticas materiales: paisajes oxidados y amarillos en la poesía de Gladys González y Andrés Anwandter ${ }^{1}$
}

\section{Material Geo-poetics: Rusted and Yellow Landscapes in The Poetry of Gladys González and Andrés} Anwandter

Macarena Urzúa Opazo

CIDOC-Escuela de Literatura, Facultad de Comunicaciones y Humanidades, Universidad Finis Terrae.

murzua@uft.cl

\section{Resumen}

Los poemarios Calamina y Amarillo crepúsculo exhiben espacios y paisajes que adquieren materialidad en el lenguaje poético. A pesar de ser poemarios muy disimiles, en ambos el espacio se configura desde una materialidad atravesada por la modernidad y su despojo. La relación entre paisaje y poesía se aborda desde el concepto de geopoética, trabajado por Michel Collot en Pour une geographie litteraire. El artículo sostiene que la memoria de los paisajes constituye en estos poemarios una ruina donde los sujetos poéticos fijan su mirada, a contrapelo de la contemplación romántica de lo sublime.

Palabras clave: paisaje, poesía chilena, materialidad, geopoética, Andrés Anwandter, Gladys González.

\section{Abstract}

The poem collections Calamina and Amarillo crepúsculo show spaces and landscapes that acquire materiality in poetic language. Despite their clear differences, both texts configure space from a materiality crossed by modernity and its residues. The relation between landscape and poetry is studied using the concept of geo-poetics coined by Michel Collot in Pour une geographie litterair. The article purposes that the poetic subjects of these poems pose their looks on the landscapes' memory understood as a ruin, instead of exercising the romantic contemplation of the sublime.

Keywords: landscape, chilean poetry, materiality, geo-poetic, Andrés Anwandter, Gladys González.

1 Este artículo forma parte de la investigación del Proyecto FONDECYT de postdoctorado $\mathrm{N}^{\circ} 3130371$ (2013-2015), titulado "Ruinas en el paisaje de la memoria. Recorrido por la producción literaria y cinematográfica chilena de la última década". 
No es suficiente "enunciar" la naturaleza utilizando el lenguaje como vehículo para que esta se vuelva paisaje. Es necesario que el idioma la recorra silencioso, vale decir, que empiece a recorrerse a sí mismo contra ella

El texto silencioso, Tamara Kamenszain.

Todo paisaje existe únicamente para la mirada que lo descubre El tiempo en ruinas, Marc Augé.

"Se echa un trozo del paisaje / que se aleja al bolsillo", dice uno de los versos de "Como volver a un país", del poemario de Andrés Anwandter, Amarillo crepúsculo (2012). Tal como el título lo anuncia y la portada del libro muestra un anaranjado atardecer, en este poema y a lo largo del libro se irán desplegando distintos espacios del territorio para configurar una identidad entre mirada y memoria, teñida con el filtro del colorante artificial usado masivamente, amarillo crepúsculo. Este es el nombre que recibe el colorante alimentario sintético, de color amarillo oscuro, usado en la fabricación de alimentos. Como si los poemas fueran imágenes realizadas con un filtro escogido para realzar una fotografía instantánea tomada con un teléfono u otro dispositivo digital, cámara o tablet, aquí se exhibe una tenue marca amarillenta en todo este mapa desplegado por la poesía de Anwandter. Por su parte, el poemario de Gladys González, Calamina, publicado en 2014 dará cuenta de otro paisaje, el puerto de Valparaíso y su condición material siempre al borde de lo ruinoso y alejado de aquella representación de la postal de esta ciudad, ahora Patrimonio de la Humanidad. ${ }^{2}$

En este trabajo se analizará el modo en que la poesía y la mirada del sujeto poético determinan una subjetividad que enmarca el espacio desde el poema. De esta manera, las imágenes proyectadas por estos textos dan forma a una geopoética, de acuerdo con lo acuñado por Collot en Pour une géographie littéraire. Los textos examinados en este artículo darán cuenta no solo del paisaje del natural sino también de la materialidad del medio que el sujeto poético en estos recorridos mostrará, conformando una geografía poética alternativa, alejada de aquella poesía que desde el romanticismo en adelante tuvo al paisaje y la naturaleza como imagen-metáfora y metonimia de lo sublime. En estos poemas, la naturaleza de la calamina y el color amarillo crepúsculo serán una puerta de entrada y, al mismo tiempo, metonimias de lo posnatural de paisajes residuos, poblados, es decir, terrenos no necesariamente baldíos, sino de lugares atravesados por materias desvencijadas, que sitúan al sujeto

2 Según la definición de la RAE, calamina es: carbonato de cinc, anhidro, pétreo, blanco o amarillento, o rojizo cuando lo tiñe el hierro. Es la mena de que generalmente se extrae el cinc. 
poético como espectador de aquel espectáculo sublime del cual el poema da cuenta. En estos poemarios, la calamina y el color amarillo crepúsculo operan como lentes para mirar ambos paisajes y, al mismo tiempo, constituyen paisajes residuos que permiten construir una geopoética de los restos.

Entre las numerosas definiciones de paisaje que trabajan el concepto desde la idea de su imaginario, estas aparecerán sobre todo a partir del cambio de paradigma en la observación y, por ende, representación de este. Creo, por lo tanto, fundamental atender a la concepción trabajada por el teórico W.J.T. Mitchell, para quien el paisaje no es solo una representación de lo natural, sino un medio de lo natural, es decir, el paisaje se constituye como una representación que es siempre de orden simbólico y un medio en sí mismo : "this 'subject matter' is not simply raw material to be represented in paint but is always already a symbolic form in its own right [...] Landscape is a medium in the fullest sense of the word [...] a natural representation of a natural scene, a trace or icon of nature in nature itself” (Landscape and Power 14-5). El paisaje se impone no solo como imagen, sino como actitud lírica de contemplación, sobre todo a partir de la poesía romántica -a fines del siglo XVIII hacia el XIX-, en donde el paisaje representado tiene que ver con la experiencia del poema, así como también con la de buscar o alcanzar una equivalencia espacial con su propia psique. ${ }^{3}$ Así se puede atender al famoso cuadro de Gaspar Friedrich, Viajero frente a un mar de nubes (1818), fijando la atención en la mirada de la figura humana hacia la contemplación de ese paisaje. Esta estética es, en cierta forma, imitada o más bien importada también por el naciente arte nacional, con exponentes como los pintores Valenzuela Puelma, Rugendas o Alejandro Ciccareli, cuyas pinturas permiten desentrañar la forma en que se miraba y se representaba el paisaje chileno, de acuerdo con los preceptos estéticos de la época, ecos del romanticismo primero, y del impresionismo después. De este modo, estas pinturas también pueden leerse como poemas, ya que más allá del marco entregado por esos paisajes, proporcionan información acerca de las ideas que estarían detrás de la observación de lo natural traspasadas a la pintura, ya sean estas vistas, paisajes o representaciones a partir de esa experiencia visual de la naturaleza.

En el paisaje y sus representaciones no puede dejarse de lado la relación con la subjetividad de quien observa, pinta o escribe, ya que así este se constituirá siempre como un medio para representar algo, al mismo tiempo que encierra en sí mismo su capacidad simbólica. ${ }^{4}$ Philipe Descola en "La gran división. La autonomía del paisaje", citando a los historiadores del arte Ernest Gombrich y Alain Roger, alude al momento en el que se sitúa la primera representación del paisaje pictórico en la pintura occidental:

3 Las referencias pertenecen a la entrada de la Princeton Encyclopedia of Poetry and Poetics, "Landscape Poem" (783).

4 Al hablar de poesía y paisaje no se puede dejar de nombrar al autor norteamericano Henry David Thoreau quien en el siglo xix defiende la vida en la naturaleza y se lo considera uno de los primeros ecologistas. Su obra más conocida es Walden: A Life in the Woods (1854), y también publicó poemas acerca de la vida en la naturaleza, Poems of Nature (1895). 
Los historiadores del arte ubican el origen del género en la primera mitad del siglo Xv, con la invención-obra de los artistas del norte de la "ventana interior" en que se recorta una vista de tierras adentro [...] Bastará entonces con ampliar la ventana a las dimensiones de la tela para que el cuadro dentro del cuadro se convierta en el tema mismo de la representación pictórica, y, al borrar la referencia religiosa, se dilate hasta ser un verdadero paisaje (103).

Por su parte, Jens Andermann, señala en su artículo, "Entre la topografía y la iconografía. Mapas y nación 1880": "Lienzo, fotografía o poema o relato de viaje, el paisaje constituye otro orden de representación del espacio, necesario porque inscribe ahí una perspectiva" (102-3). Es decir, el orden de reproducir la idea de un espacio en otro medio, de traspasar esta experiencia a través del lenguaje a otro soporte, implicará -desde la invención de la imprenta en adelante- un cambio en la percepción, que fue lo ocurrido con el surgimiento del género de la pintura de paisaje. De este modo, según Andermann, podemos leer el poema desde este lugar, en su condición de entrada a otro orden de representación en donde la subjetividad tiene un rol fundamental. El espacio del poema siempre dependerá de la mirada que le otorga el poeta, ya que el establecimiento de la idea de paisaje -según la percibimos hoy, desde la imagen y la centralidad de la mirada humana- no habría sido posible sin la concepción de la subjetividad. Por ende, tiene que ver directamente con la aparición del hombre, de la figura humana a escala en la pintura de paisaje, que incluye a esta imagen contemplando el espectáculo natural, es decir, al centro de pinturas en donde prima la naturaleza y la presencia de la mirada está en la contemplación del paisaje. El término paysage en francés o landscape painting en inglés, correspondían a un género menor de la pintura que justamente se inspiraba en la contemplación de lo natural para traspasarlo o copiarlo a la tela.

Como una primera hipótesis, propongo que estos poemas de Gladys González y Andrés Anwandter operan casi al opuesto de la búsqueda de la poesía clásica -retomada por el Siglo de Oro español del locus amoenus- y tampoco se acercan al ideal de la poesía romántica que celebra al paisaje y su naturaleza. Es decir, aquí la mirada del sujeto poético ve desde la subjetividad del paisaje, apropiándose de este a partir de una mirada multitemporal que muestra una percepción de este, traspasado por fragmentos, residuos y materialidades que exponen otra relación con lo natural. El sujeto poético ve otros colores al mirar el entorno de lo natural. Surgen así el amarillo crepúsculo y la calamina, es decir, apropiándose del ambiente natural y agregando también el componente de lo artificial. Si bien la poesía no da cuenta de la distinción entre estos tropos y figuraciones del lugar, sí es la palabra poética la que nos entregará a los lectores la subjetividad del sujeto poético, con la cual podemos o no identificarnos. Por tanto, el poema atiende al paisaje desde un espacialidad y temporalidad particular, que sitúa al poema, al lector y, por ende, a la relación entre ese espacio retratado y el sujeto poético. En este punto, creo fundamental atender a la relectura 
que hace Jacques Rancière en "De la poesía del futuro a la poesía del pasado" sobre la lírica del romanticismo -aludiendo al texto de Schlegel, Lecons sur la littérature et l'art, en cuanto a la potencialidad del fragmento como un germen (80)-donde señala: "La poética del fragmento proporciona entonces la unidad anhelada entre el principio de igualdad y el principio de simbolicidad. El fragmento es símbolo: trozo cualquiera y microcosmos de un mundo. Es libre fabricación de la imaginación y es forma viva transportada en el movimiento de las formas de la vida" (83). De manera que tal potencialidad de estos paisajes fragmentados será presentada en los poemarios que se analizarán a continuación. A partir de la materialidad de esos fragmentos coloridos como el armarillo y el óxido de la calamina, se pintarán paisajes poéticos que emergen de la experiencia y la observación, de la precariedad de lo moderno, y de lo sublime de un paisaje, un atardecer (fig. 2) y un fragmento de un lugar que podría ser cualquier ciudad urbana o rural del Chile actual (fig. 1).

Chris Fitter en "Toward a Theory of Landscape" se refiere a la presencia del paisaje en la poesía del siglo XVII inglesa y sostiene que la pintura de paisaje tiene una incidencia en estos textos, de ahí el concepto ut pictura poiesis: "a landscape, no less than a text, is 'read' by mutable 'interpretive communities'” (8). Es decir, Fitter apela al hecho de que cada comunidad interpretará y leerá ese poema y el espacio allí retratado, de acuerdo a una sensibilidad enmarcada en lo temporal, así como también en el espíritu de la época: "Within our historical survey we shall accordingly seek to characterize each period's nature-sensibility, which is always a product of its particular economic structure and its working relations with the earth, its social conditions and formal thought; and then suggest the mediated, peculiar forms of landscapeconsciousness" (9). Este concepto es fundamental para atender a una mirada de estos paisajes posrománticos; sin embargo, más cercanos a una instantánea de lo actual en donde la palabra y cierta sintaxis nos acercarán a estos espacios. Michel Collot acuñó el término "geopoética" para referirse a la relación que se establece entre geografía y poesía según lo explica en Pour un géographie littéraire. Con este concepto, destaca la idea de que las poéticas del lugar se inscriben también en las palabras. Collot propone buscar una definición estrictamente literaria para lo geográfico, ya que una geografía verdaderamente literaria no puede negar la letra ni lo literario de los textos que estudia (120), de manera que distingue tres dimensiones del espacio en el que se inscribe una obra literaria y cómo debemos aproximarnos a cada una:

L'espace que déploie un écrivain dans une œuvre littéraire, a, comme le signe linguistique, trois dimensions: il renvoie à un référent dont il propose une image, qu'il revêt d'une forme pour lui donner un sens. Son analyse devrait donc s’efforcer d’associer approches géographiques, géo critiques et géo poétiques (129).

Así, a partir de estos enfoques, es posible a través de la poesía determinar la relación entre paisaje, sujeto, territorio y poética, y observar cómo el territorio es trabajado desde una perspectiva crítica, en este caso una geopoética que permite pensar una 
aproximación al lenguaje de la poesía desde los espacios que muestran los poemarios Calamina y Amarillo crepúsculo. Analizaré algunos poemas para ilustrar la manera en que es percibido el paisaje desde la subjetividad de la mirada en ambos sujetos poéticos y la materialidad que da cuenta de un cambio en el foco representacional, así como también en la contemplación de estos espacios. Para Héctor Hoyos en la introducción al dossier "La cultura material en las literaturas y culturas iberoamericanas de hoy", publicado recientemente en la revista Cuadernos de Literatura 40 apunta a este creciente foco en la materialidad, que atendería a un fin de la representación mimética de la realidad en el arte, desplegada de cierta espiritualidad. Según Héctor Hoyos: "A contrapelo de la teoría dualista de la mímesis, en la que la literatura y otras artes reflejarían lo material en lo espiritual, se abre paso un pensamiento más matizado sobre la compleja interacción interna entre creación y realidad" (256). Es decir, podríamos afirmar que hoy no podemos pensar en el paisaje y su presencia humana dejando de lado el materialismo, la materia que rodea, como lo constata Hoyos, siguiendo las ideas planteadas por Diana Cool y Samantha Frost, en la introducción a New Materialisms. De manera que nuestra forma de relacionarnos con el entorno, de reproducirnos, alimentarnos y afectarnos con lo vivo y lo no vivo estaría traspasada por las materialidades a las que nos vemos enfrentados en nuestra cotidianeidad ("Introducing the New Materialisms" 5-6). Estos poemarios -y sobre todo Amarillo crepúsculo de Anwandter desde su título- dan cuenta de una transformación del entorno desde la imposición del uso universal y masivo del consumo de productos alterados por la tecnología, como es el caso de la tecnología alimenticia y la implementación de colorantes en la cotidianeidad de todos.

\section{Sobre Calamina: poetizar el paisaje desde lo material}

En primer lugar, el poemario de Gladys González exhibe en su portada una entrada visual a lo que será el libro: una imagen de la lata oxidada con un particular encuadre, que alude a múltiples viviendas que pueden exhibir en su exterior esa calamina roída por la humedad. Material que da cuenta de la precariedad en oposición al imaginario del puerto, que se ve en las postales de promoción turística. Este material es el que nos otorga una entrada al poemario, al espacio y al paisaje que irá dibujando el sujeto poético de Calamina en su recorrido por el puerto de Valparaíso. 
FIGURA 1

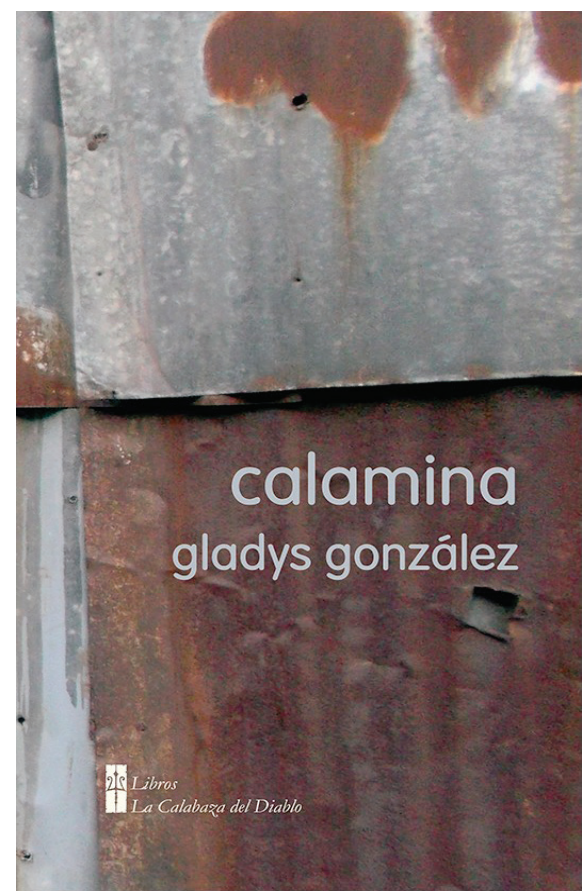

Portada de Calamina. La Calabaza del Diablo, 2014.

Así puede verse en un fragmento del poema "Habitaciones" de Calamina:

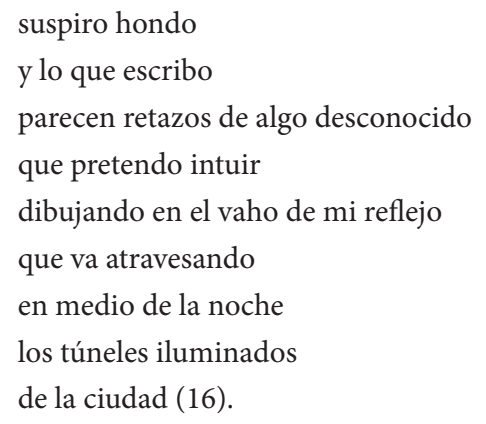

En esta porción del poema, el espacio del texto se sitúa desde un yo íntimo que muestra una huella de lo corporal que altera la visión del exterior, dejándola en ese espacio, como lo señala el siguiente verso: "dibujando en el vaho de mi reflejo"; es decir, haciendo una marca en esa escena, como gesto que atraviesa la noche y termina en la ciudad solo iluminada por un túnel y la huella de luz que sale de ese espacio cerrado. El poema en sí pareciera encerrar ese vaho y proyectar la experiencia del cuerpo hacia la memoria del espacio, del recuerdo de las luces que se asoman en la ciudad. De ese modo, el poema se sitúa desde la perspectiva de la mirada y nos habla 
de lo íntimo, el suspiro, el intuir, el vaho, de lo corporal que revela intimidad para pasar a "los túneles iluminados / de la ciudad", como dice el verso. El poema es un recorrido que nos lleva por distintos espacios a preguntar acerca de qué tipo de lugar está siendo desplegado aquí, un paisaje intervenido, como el que aparece en "Óxido":

observo el atardecer
recostada sobre el techo
respirando la humedad de la tarde
entre el vuelo de las gaviotas
que se incendian entre las nubes
y las calaminas
secándose al sol
revelándose
en el silencio del óxido
un paisaje
de metales quemados
enredaderas silvestres
hombres solitarios
hurgando en la basura
de casas demolidas
un paisaje
que concluye silencioso
cuando el horizonte desaparece
tras las luces amarillas
en medio de la bruma
que se levanta del mar ( 23 ).

El sujeto poético reitera con el verso "un paisaje" tanto la descripción desde una mirada introspectiva como un modo de habitar este paisaje en el poema. Un paisaje de residuos, ruinoso, ya que no distingue entre qué constituye un presente del paisaje o bien su pasado. Es un texto que exhibe la materialidad y la visión de lo desechable, otra visión de lo sublime, donde la calamina aparece como sinécdoque de los paseos del puerto. Asimismo, si observamos los colores del poema podemos advertir los naranjos del atardecer, los metales quemados, las luces amarillas "y las calaminas / secándose al sol”, es decir, los techos de las casas doblemente enrojecidas y gastadas por ese "silencio de óxido" que tiñe todo el paisaje al caer la tarde. Las calaminas parecen incendiarse tal como la descripción de dicho atardecer. El tono del poema -en primera persona- remite a una intimidad y a un paisaje que desde una subjetividad da cuenta de los residuos visuales que la mirada del sujeto poético logar tornar en un paisaje romántico -diríamos apocalíptico quizás-, alejado de la belleza sublime de la contemplación de lo natural, más bien "un paisaje / de metales quemados". En este texto, el instante es el poema el espacio y tiempo confluyen en la textualidad del 
ritmo y de la mirada fotográfica que entrega el sujeto poético. Al igual que los versos "un paisaje", el óxido que se oye y huele es reiterado, invadiendo todo el texto y el paisaje, reemitiéndonos a la materialidad de la calamina: residuo, resto y rastro de un mundo fragmentado que nos muestra desde su composición el lugar que posee la calamina en ese paisaje del puerto. La calamina en sí misma habla de una materialidad con que están hechas numerosas casas tanto en los cerros de Valparaíso como en el sur de Chile y en muchas viviendas de Santiago. Al ser un material de construcción recurrente en tomas, poblaciones, campamentos, la calamina aparece en tanto un material que alude a la precariedad, al sonido de la lluvia que la golpea y lo amplifica. Aquellos objetos que están expuestos a la intemperie, dejados para oxidarse y convertirse en residuo, resto, fragmento, aluden una imagen de ruina, que vuelve a hacerse presente tanto a partir del romanticismo en la literatura y la pintura, así como también se observa en un poemario de vanguardia como The Waste Land (1922) de T. S. Eliot. ${ }^{5}$ La condición precaria de la vivienda entrega una mirada sobre el paisaje, tal como si viéramos desde arriba esos techos hechos de calamina en un atardecer que parece fuego, como lo señala el sujeto poético de "Óxido".

La crítica Lorena Amaro, en la presentación del poemario de Gladys González, señaló que en Calamina el arribo a los cuerpos y la subjetividad tramada en ellos se hace: por el contrario, muy lentamente, como si las palabras avanzaran abriendo el paisaje, un paisaje que se encuentra no "aquî", sino allá, en la distancia, en los cerros de la bahía, imagen inaugural de este nuevo texto: "los cerros / parecen un parque de diversiones / torcido / interminable / lejano". [...] Con estos poemas, Gladys rasca la calamina de un paisaje ajeno, la bahía, el puerto, hasta hacerla brillar, rojiza, en su desgaste, en su calamidad.

En este sentido, en tanto lectores y espectadores de estos paisajes, podemos preguntarnos: ¿desde dónde se nombra el espacio? ¿Se lo dibuja como un paisaje natural o una ruina? Lejos del paisaje utópico de la modernidad -o la idea de la ciudad globalizada- vemos en la poesía Andrés Anwandter y Gladys González un espacio urbano, a veces, desbordado, fracasado en su modernidad. Lucía Puppo se pregunta en su reciente libro sobre poesía, Entre el vértigo y la ruina, dónde está la naturaleza presente en la poesía contemporánea o si esta es, más bien, un paisaje desde donde surge la ruina. En la introducción señala:

Como la visión anortoscópica, la poesía explora los límites difusos de la cercanía y la distancia, el todo y la parte, la confianza y la sospecha, la pertenencia y la

5 Según Helen Vendler, Eliot intentó retratar: “The multilingual cacophony of Eliot’s fellow patients in Lausanne” (81) y cita los siguientes versos de The Waste Land: "In the mountains, there you feel free. / I read, much of the night, and go south in the winter” (81). Así para Vendler, la mezcla presente en esta sección inicial del poema muestra la desesperación llevada también al ámbito del paisaje: "Into this mélange, there breaks the despairing protagonist's dialogue with himself, carried on a landscape of aridity, brokenness, and exposure to a pitiless sun...Both the protagonist and his landscape mutate in protean ways, but the bitter suffering underlying the central voice remains the same" (81). 
pérdida. Es por eso que la pregunta por el espacio en poesía no tiene que ver con un afán métrico, mimético o totalizador, sino con el acto de restituir una experiencia, de devolverle al espacio su contexto vital, simbólica y afectivo [...] Todo poema evoca un espacio, referencial o imaginario, a partir de la enunciación de un sujeto y de su peculiar focalización o punto de vista (11).

Puppo además recurre a otro concepto -también acuñado por Michel Collot en su libro Paysage et Poesie- que alude al hecho de que en poesía existe aquello que se ha denominado un "pacto lírico" entre el yo las palabras y el mundo (11). Por su parte, Gwen Kirkpatrick en su ensayo "Poetry in Ruins: Scenes of Destruction or Renewal?” sostiene que el tópico de la ruina ha sido el foco de nuevas meditaciones acerca de la historia, una remembranza alegórica de nuestra fragmentaria y fugaz comprensión (167-8). Si la poesía hasta el siglo xix intentó ordenar el mundo y pasa a ser parte del discurso público - por ejemplo, con Andrés Bello y José Martí-, esto se diferencia de lo que sucede con la poesía moderna, "In the same way, modern poetry, to a great extent, has rejected order and coherence as guiding values and has stressed the poverty of language and its inability to provide this order and coherence" (178). Kirkpatrick observa, sin duda, un contraste con la poesía aquí presentada, es decir, una donde prima lo fragmentario, el descreimiento de los grandes discursos, del poder representacional de un texto y, en algunos casos, la repetida aparición de la ruina, lo baldío en tanto imagen que se hace presente en varios poemarios que abordan el tópico del paisaje o la ciudad. Aquí, la palabra ocupa un espacio y tiempo determinado y, en cierta forma, ordena, organiza aquello que pasa por la mirada. En el siguiente poema "Pequeños espacios” de Gladys González se exhibe parte de una escena callejera de Valparaíso:

los caminos de la bahía
llevan a pequeños espacios del dolor
que permanecen silenciosos
un hombre
está tirado en el suelo
como un animal destripado
los pantalones abajo
sus genitales congelándose en la lluvia
un perro sostiene su cabeza
como si de ese hombre alcoholizado
dependiera su mundo (13).

En este poema, el sujeto poético ocupa el lugar del testigo, dando cuenta con esta imagen grotesca de la destrucción de ese paisaje, de un entorno que cambia constantemente y que deviene en parte en una ruina. El poema construye su imagen no solo con palabras, sino también con lo no dicho, con lo anónimo de ese hombre no identificado que yace en el suelo descrito como: "pequeños espacios de dolor". Estamos 
ante un paisaje de fragmentos y residuos, alejado de un paisaje romántico, sublime para la contemplación. Esta misma idea es reforzada por la poeta argentina Diana Bellesi, al señalar que el paisaje ingresa al poema desde la "mirada inmanente" del poeta, aquella que "coloca al yo del que escribe abierto en su vulnerabilidad" (79), atento al pulso leve del detalle y las pequeñas cosas. ${ }^{6}$

\section{Otro color que tiñe el paisaje: el amarillo crepúsculo}

When one knows that something will soon be removed from one's gaze, that thing becomes an image.

Walter Benjamin

"Es un libro en tono de extinción, de fin de época, de agotamiento y catástrofe" (47), señaló el crítico José Ignacio Padilla al referirse al poemario de Andrés Anwandter, Amarillo crepúsculo.

En Amarillo crepúsculo, el sujeto poético recorre el territorio y despliega un espacio en donde imagen e historia devienen fragmento, adquiriendo la dimensión de un residuo que se atraviesa y desde el que aparece esta mirada inmanente. ${ }^{7}$ Aquí, el sujeto poético se refiere mayoritariamente a un territorio inacabado, del mismo modo en que lo son el lugar del discurso, la estructura de los poemas y su disposición a lo largo del libro. Se vuelve difícil situar el comienzo o el fin de Amarillo crepúsculo, debido a que se lee como un gran continuo o, más bien, como un gran y único territorio. Esta zona del poema, va siendo apropiada por la mirada del sujeto poético, quien entrega una imagen mediada por la reflexión y por la historia. Además, incorpora estos espacios como una cartografía afectiva y poética desde dónde se sitúa su discurso. Así se lee en el siguiente poema, "No miré con atención los saqueos":

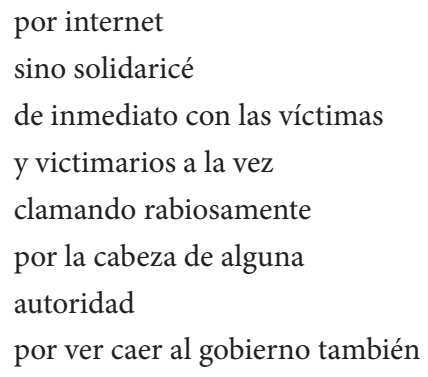

6 Citado en María Lucía Puppo, Entre el vértigo y la ruina.

7 Recomiendo leer el artículo de Javiera Lorenzini que aborda este poemario en relación con la poesía experimental, "Poéticas de la erosión: experimentación formal y crítica política en Amarillo crepúsculo de Andrés Anwandter", publicado en Revista Laboratorio (2013). 


\title{
FIGURA 2
}

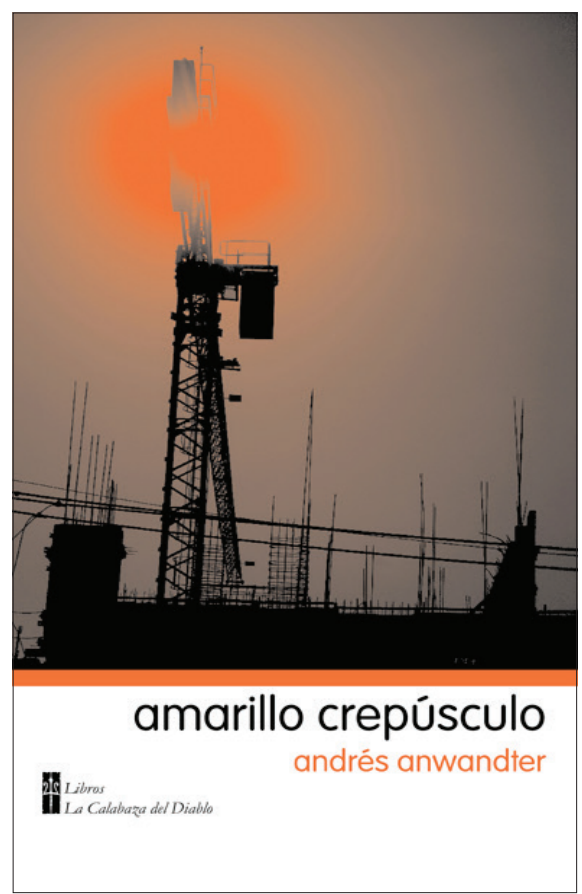

Portada de Amarillo crepúsculo. La Calabaza del Diablo, 2012.

\author{
junto a sus obras \\ concesionadas \\ surgiendo entre las ruinas \\ un capitalismo más puro \\ verde claro \\ como los brotes de pino \\ que asomarán en hileras \\ en los predios forestales \\ fuera de la zona de la catástrofe (208).
}

Varios de los textos que componen el poemario aluden al terremoto de 2010 y la ruina acaecida en el territorio como consecuencia de la catástrofe. En particular, este poema da cuenta, por una parte, del cambio en el territorio, de la falsedad del gobierno, las promesas de la política, vinculadas al título, y por otra, del nombre del colorante en tanto forma de leer el presente. Esto se advierte con la afirmación de la contratapa: "Aquel edulcorante como anagrama de lo real". Es decir, aquello que falsamente puede endulzar y teñir una realidad para no dejarla ver nítidamente; por tanto el poema constituye un territorio que no se termina de ver, en el que: "[...] asomarán en hileras / en los predios forestales / fuera de la zona de catástrofe". En 
otro fragmento del poemario, titulado "Apenas una sola", aparece la idea de despojo y pérdida también asociada al paisaje: "un viento ha barrido con la cordillera / subyace a los cerros pelados / Santiago".

A través de estos versos puede verse una alusión a aquella imagen icónica de la ciudad aquí nombrada, Santiago, así como también a los cambios que enfrenta, debido a la modernidad, a lo no perceptible a primera vista, pero que cambia constantemente y se hace visible. La imagen característica de la cordillera desaparece para dar lugar a los "cerros pelados" y con esto, a un territorio cuyo imaginario ha devenido peladero, dando paso a una imagen lejana a la típicamente asociada a esta ciudad, es decir, la cordillera de los Andes. Esta suerte de conciencia del cambio y la pérdida de cierto paisaje e identidad de la ciudad -y del imaginario cultural que se le asocia- puede observarse a partir de la nostalgia expuesta en esa especie de postal de la ciudad que contiene "Para darle marco":

a los rascacielos en el fondo
diseñar las montañas de nuevo
aprovechando su desplome
político en los medios
rodeado de micrófonos
y móviles discretos
servicios a cambio de más
................................
esta noche
me trae recuerdos de Chile
olor a parrilla y bandadas
de pájaros que se dirigen
allende el mar
la cordillera
como decían las canciones
de otras épocas (234-5).

El poema remata con "decían las canciones / de otras épocas"; versos finales con los que se alude a un pasado, teñido de nostalgia, que sitúa al texto en un espacio de la canción conformado por la cordillera. En ese lugar afectivo donde se enmarca el texto se centra también la mirada, vale decir, en el pasado desaparecido, mezclando un discurso inexistente con un paisaje que también se difumina. El título "Para darle marco" permite leer el poema citado desde justamente un lugar preciso, señalando una marca en un mapa que, en este caso, es el marco, como aquel elemento que encuadra una mirada, en una fotografía, ya sea en un cuadro o en una publicación, un recorte. Este hecho de seleccionar y dejar algo fuera siempre implica un área a destacar en desmedro de lo que quedará fuera de foco, fuera de un sitio para así resaltar otra figura. En la estructura del poema es posible ver el uso de versos cortos y encabalgamientos 
que acrecientan la idea de lo inconcluso, de elementos nombrados o reunidos al azar, a los que el sonido de la doble "l" -fonema que se repite en distintos versos: "parrilla", "allende", "cordillera" - pareciera darles cierto orden. De modo que la sonoridad del poema le entregará unidad a su estructura y también sentido, ya que lo recordado son "las canciones / de otras épocas". La memoria y aquello que le da forma y estructura aparece acá, mediada por internet y por la televisión que, sin duda, se hacen presentes, como se ven en el siguiente fragmento del poemario:

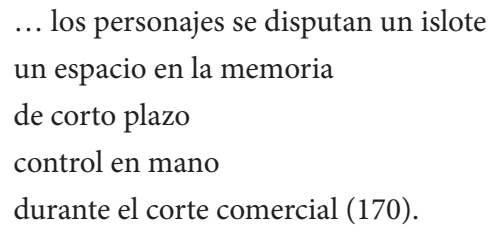

El espacio para la memoria es de corto plazo y exhibido como un fragmento con una fisura, o más bien un corte que está mediado por la televisión, haciendo aparecer a la contingencia críticamente descrita por el sujeto poético. Es decir, aparecen discursos que llevan incluso a dibujar otro mapa del territorio nacional, ya no intervenidos por la contemplación del paisaje sino que por los medios de comunicación masiva. Así puede leerse en otro extracto de Amarillo crepúsculo:

\author{
NI SE DESPEINA A PESAR \\ de todo el candidato \\ ofrece por televisión \\ imágenes suyas al viento \\ la cara radiante \\ en una cumbre \\ a decir verdad \\ de escombros \\ pero hablando sin pausa \\ mientras baja de la cima \\ rodeado de micrófonos \\ o teléfonos en su defecto \\ capturan sus palabras \\ las adaptan a una línea
}




\author{
editorial se difunden \\ por todos los medios \\ confundiendo a las audiencias \\ con el rating \\ el mapa con el territorio \\ antártico nacional (210).
}

El poema citado, como tantos de los otros que componen el libro, se concentra en los escombros, en los fragmentos, en esas imágenes que aparecen en el texto, cortadas y capturadas para los medios de televisión. Remiten a un momento, un espacio en el tiempo que, sin embargo, posee un efecto mediático: el de confundir a las audiencias a tal punto que se asimila al mapa con el territorio antártico nacional, como dice el último verso. Resulta interesante que este texto, además de mezclar indistintamente el espacio natural de la cumbre de un cerro o montaña con la irrupción de la mediatización de las palabras -en este caso de un político-, coincida con la creación o más bien confusión en cuanto dibuja un mapa de un territorio casi deshabitado y sin mayor representación para la configuración de un paisaje de lo nacional o de lo chileno, como lo constituye la antártica. El viento no despeina, dice el poema, el mapa no se dibuja, las audiencias se confunden; es decir, es un texto que ofrece imágenes que se reflejan pero no tienen sentido, tal como lo señala en otro poema: "Cómo volver A OTRO PAÍs/ sin tropezar con uno mismo" (221).

Amarillo crepúsculo es un poemario que, a partir de las imágenes, critica y cuestiona las luces intermitentes que entrega la lectura de los poemas. Digo intermitentes porque ese afán de sentido, que a veces se impone desde la lectura, se escapa de nuestros ojos de lectores. Sin embargo, quedan imágenes como las de la luz última de un crepúsculo. Los mapas quedan en el lugar de la televisión y el lenguaje es el que, finalmente, arma, crea y desarma aquello que tampoco es referencial, más bien son sonidos, visiones, residuos, y citas. José Ignacio Padilla, en el texto ya citado, habla de: pequeñas denuncias y pequeñas epifanías surgen en el espacio familiar, personal, interior, constituidos siempre por los restos simbólicos del exterior [...] En este crepúsculo no hay ni interior ni exterior, sino un uso particular del lenguaje; digamos, un uso no mimético: en el sentido de que el lenguaje no funciona como un instrumento transparente para recrear una realidad dada (47).

Para Padilla, el lenguaje solo cuenta, enumera, no arma o crea un sentido, más bien exhibe restos, incluso aquello que sería parte de lo que él llama "discurso de la realidad" quedaría también opacado dentro del texto. 
Por su parte, Matías Ayala señala que Amarillo crepúsculo "se compone de poemas que son montajes -en el sentido cinematográfico- de imágenes, reflexiones, escenas, recuerdos y sensaciones". Sin embargo, creo que dichas imágenes y sensaciones configuran un paisaje, a pesar de dar cuenta de cierto agotamiento de los residuos que pueblan todo el poemario. Como su título lo indica, es un amarillo artificial que tiñe desde el paisaje de la fotografía de la portada hacia adelante. Una imagen similar matiza y colorea la percepción de un territorio delimitado, según el sujeto poético que deambula por el puerto de Valparaíso en "Nocturno de bahía”, poema que integra Calamina de Gladys González:

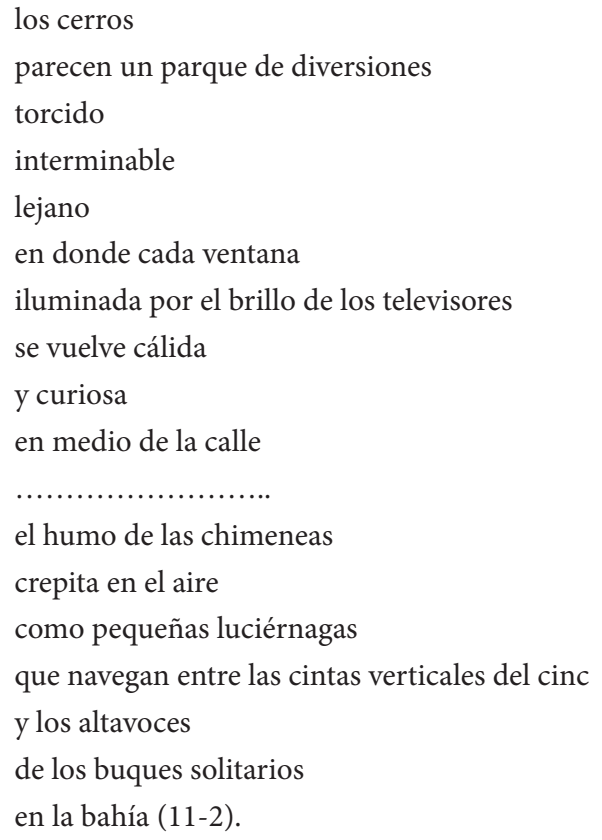

Si atendemos a la estructura del poema, a sus versos cortos y al uso repetido de ciertas palabras que usan vocales cerradas -que, por ejemplo, entregan a la lectura los sonidos de "i", "u", al leer: "cintas verticales del cinc" (el destacado es nuestro)- o bien el sonido que forman las vocales "u" en: "humo", "luciérnagas", "buques", es posible reconocer la creación de un paisaje que es a la vez sonoro y rítmico mediante la repetición de sonidos vocales que remarcan esa acentuación en las primeras sílabas. De este modo, tales combinaciones sonoras son referentes de espacios, particularmente abiertos, pero que al mismo tiempo denotan intimidad. Por ejemplo, una luciérnaga, navega en el cinc, y con ello se crea una imagen dentro del texto que contiene a la luz, entregándole así continuidad al remate del texto que prosigue con la siguiente escena: el sonido solitario de los buques en la bahía. Este paisaje es uno que ofrece cercanía, al mismo tiempo que contrasta con el sonido provocado por las vocales al leer los versos iniciales del texto, aquellos que muestran a un espacio abierto, como 
"el parque torcido interminable lejano". El poema de González nos señala un espacio visto desde el sujeto poético, proponiendo una mirada del paisaje desde la subjetividad. En el texto, además, son nombrados elementos que son típicamente asociados al puerto de Valparaíso: los buques, las luces de los cerros, el humo de las casas, los reflejos en las ventanas, el cinc, los altavoces que retumban desde el puerto. Aquí, tanto los sonidos como la mirada del sujeto poético cobran igual relevancia para configurar este cuadro nocturno del puerto. Por su parte, las ventanas como ojos -recurso ampliamente usado en el cine- acá se trasladan al lenguaje del sujeto poético, quien las recrea con la mirada. De ese modo, es posible percibir una particular percepción del paisaje y sus cambios experimentados -tanto desde dentro como fuera- en una naturaleza que también va mutando.

Jean Louis Comolli alude al recurso de la ventana en el cine, apuntando a la idea expuesta anteriormente por André Bazin: "Encuadrar es sustraer a la vista todo lo que no está en el encuadre. En cuanto ocultador, este no solo encubre una parte más o menos importante de lo que se deja ver del mundo visible, del campo visual, sino que impide ver lo que aún no está encuadrado o lo que ella no lo está" (38). En "Nocturno de bahía", la ventana se abre como un dispositivo que nos permite a nosotros lectores / espectadores mirar hacia adentro de esas casas. El título del poema contiene la palabra "nocturno". Este dato nos entrega otro elemento para leer este texto, que alude al nombre que recibe la composición musical típicamente romántica. En el poema de González, este paisaje romántico se ve modificado: la imagen romántica del puerto de noche, con los barcos reflejándose en el mar, sería trastocado por las luces de la televisión que se reflejan en los vidrios, luces que en lugar de navegar en el mar, lo hacen en el techo de zinc. El nocturno, forma recurrente sobre todo en la poesía llamada órfica -en la cual el poeta romántico desciende a la oscuridad de los infiernos-, puede leerse aquí como una relectura del tópico de lo nocturno en un entorno urbano y ruinoso. Sobre este punto, la crítica Susan Stewart sostiene: “The story of Orpheus underlies every poem. The poet risks the dangers of silence and darkness... I want to think about the ways the Orphic journey into darkness is a prototype for the claims poetry makes against mortality. The poet's nocturnal wandering is a mythic archetype found throughout a number of cultural traditions" (256).

El motivo del nocturno ha sido recurrente en la historia de la literatura, particularmente en la poesía. De allí que podamos leer este poema citado de Calamina como una relectura, un recorrido, un wandering por el puerto nocturno. Su descripción de tintes románticos construye otro espacio del puerto, sin duda reconocible. Incluso me parece advertir cierta similitud con el siguiente pasaje de Chile o una loca geografía (1940) de Benjamín Subercaseaux, ubicado en la sección titulada "Donde Valparaíso aparece muy lejos o muy cerca, según el camino que tomamos": "De noche, las luces desparramadas profusamente por cerros y avenidas dan cierta seguridad al paisaje que, sin ellas, parece partir a la deriva, empujado por el viento sur. Las rachas son violentas; las luces, inmóviles" (132). Estas ventanas que intervienen como ojos se 
pueden relacionar también con aquella imagen del poeta vanguardista que mira el mundo por la ventana del tren o "del hombre cámara [que] le servían como emblemas del poeta vanguardista: percepción fragmentaria, discontinuidades, nuevas relaciones entre objetos distantes y la distancia misma incorporada en la percepción por la mediación de la tecnología" (Padilla 261). ${ }^{8}$

\section{Conclusiones}

Por tanto, al preguntarnos por cómo se actúa y cómo se subjetiviza esta geografía, una posible respuesta es desde la escritura en la que el sujeto poético va internalizando ese espacio para crear otro paisaje poetizado y poetizable. Tal es el caso de los dos poemarios aquí abordados. El paisaje de lo artificial del colorante que lo tiñe y de la calamina que lo oxida fijan ese espacio de otra forma. De ese modo, ambos poemarios crean diversas cartografías del territorio existente.

La académica Magda Sepúlveda en Ciudad quiltra. Poesía chilena (1973-2013) considera que, a partir de los años noventa, parte de la poesía chilena se sitúa en terrenos baldíos, y sostiene: "Son los nuevos ciudadanos, sin tiempo, sin historia, caracterizados solo por fragmentos” (159). Sin embargo, agregaría que esta fragmentación continúa y no remite solo a la ruina, sino que también a una zona crítica en donde ingresa el poema: un espacio propio desde la mirada del lugar y los paisajes que toman posesión a través de los afectos, una mirada que critica el paisaje y la ciudad en donde se inscribe el descontento de quienes lo habitan. Una cartografía íntima, lejos del primer mundo, más cerca de ser un país o una comarca en miniatura, de la experiencia traspasada por los afectos y por un territorio que se resignifica con la mirada del poeta. Una cartografía de paisajes y colores como el amarillo crepúsculo y el tono de la calamina oxidándose remite a otros mapas trazados desde la subjetividad, donde se vuelven reconocibles en el poema los colores como si fueran marcas de esta nueva topografía geopoética. Según Michel Collot, para logar una aproximación geocrítica de la literatura, hay que volver al texto, leerlo atentamente para descubrir su paisaje:

Une géographie véritablement littéraire ne peut que mettre en crise toute tentative de cartographie. Celle-ci ne saurait en rendre compte, surtout si elle est générée automatiquement à partir d'une base de données textuelle. Pour y parvenir, il faut retourner au texte, et le lire de près pour découvrir son paysage, qu’on ne peut trouver ni figurer sur aucune carte. Et cela, c'est la tâche d'une approche géo critique (“Approches Géographiques” 85).

8 En el apartado "La mediación incorporada", Padilla remite al ensayo de Francine Masiello sobre la ventana de la vanguardia de su libro Lenguaje e ideología. Las escuelas argentinas de vanguardia. 
De este modo, Collot continúa su análisis para plantear que esa llamada "poética de los lugares" se inscribe también en las palabras. Además, sostiene que el paso de lo geográfico a lo poético a menudo opera a través de una naturalización de los actos de habla, que continúa siendo demasiado metafórica ("Aproches Geópoetiques" 119). De ahí que la poesía y esas construcciones metafóricas de paisajes hechas de palabras permitan inscribir estos textos dentro de la idea de la geografía literaria, específicamente de una geopoética. En estos poemas tanto los ritmos como los fragmentos y montajes se suceden como metáforas de un sujeto poético escindido ante las vistas de los diversos territorios. El sujeto poético observa, percibe, describe y transita para desplazar esas vistas y paisajes, haciendo que nosotros -los lectores- entremos en esas cartografías poéticas dibujadas por el sujeto en el poema; comprobando la indisoluble relación entre poeta, espacio, subjetividad. Esta correspondencia entre sujeto poético y espacio ha sido observada por Francine Masiello en "La naturaleza del poema”, sección de su libro El cuerpo de la voz. Ahí señala que son los poetas quienes reproducen la inmediatez del paisaje en sus voces y sus cuerpos (109), aludiendo con esto a la relación que se da entre paisaje e intimidad en la poesía: "El paisaje crea su propio lenguaje, sus miradas, sus materias, sus cuerpos. Ubica a la poesía en íntima relación con lo visto. De esta manera, el paisaje cambia la mirada de quien lo ve" (110).

Los poemas aquí presentados son analizados en relación con el paisaje y el concepto de geopoética que, en los textos de Anwandter y González, adquieren una particular visión del entorno, dibujando un recorrido y un mapa. Nocturnos de bahía, paisajes oxidados, teñidos de colores artificiales, enmarcados por la catástrofe, devienen paisajes que exhiben en sí mismos fracturas del lenguaje y la sintaxis de manera que conforman imágenes ruinosas, escenas cuyos enfoques toman la forma de los afectos, de una geografía que dibuja un mapa afectivo. El texto, como un espacio que aúna experiencia y lenguaje, se traduce a un poema. Podríamos afirmar entonces que es el lenguaje poético una última frontera entre el paisaje representado y el modo de habitar un espacio para el sujeto. Es así que esa mirada se transluce y traduce en un poema, develando esta geopoética al enfrentarnos como lectores al poema. El espacio en la literatura no es referencial, ya que plantea desde el origen un lugar fuera del lugar $y$, asimismo, es una marca temporal. Se erige, entonces, un paisaje liminal que es el espacio del poema, una geografía traspasada por el texto. La idea de una geopoética responde al modo en el que, por un lado, se poetiza el espacio, y por otro lado, se crea un imaginario del territorio que, atendiendo a una definición del paisaje desde la subjetividad, crean otro mapa, otro paisaje. Es decir, una geopoética remite siempre a la mirada del sujeto poético. Podemos, en síntesis, señalar que el lenguaje poético se presenta como una frontera entre la realidad y ese otro lugar que funda la poesía, la fuerza creadora que infunde a aquello que inscribe el acto de ese lenguaje. La forma de operar sería el espacio poroso entre lo real y la mirada del sujeto poético, aquello que deriva en una frontera; en cuanto es una línea siempre movible e imaginaria que 
denomina temporalmente un lugar que no se puede habitar, pero que siempre está del otro lado: diremos que este es el lugar del poema.

Aquel sentimiento de lo romántico -señalado anteriormente y aquí citado según los puntos de vista de Chris Fitter y Susan Stewart- es el punto de partida en estos poemas, los que, sin embargo, no pueden leerse alejados de la constatación de la ruina de esa naturaleza que ya no es salvaje, ni sublime. Desde esta perspectiva proponemos leer un poema como "Nocturno de bahía" de Calamina o poemas como los ya citados de Amarillo crepúsculo: paisajes ruinosos teñidos de un pasado romántico que, en la historia de la literatura, tienen su origen en el contemplar, en ese sentimiento sublime hacia la naturaleza tal como aparece en el conocido cuadro del pintor romántico alemán, Gaspar Friedrich. Sentimiento que, desde las miradas de ambos sujetos poéticos, no evocan un locus amoenus, sino que son una perspectiva crítica ante el entorno que poetiza a partir de despojos. De esta manera, la poesía tiene la potencialidad de devenir una resistencia a la mirada romántica del paisaje. De ese modo puede leerse en el poema titulado "Cuesta tanto", del último poemario de Andrés Anwandter, Adverbios terminados en mente (2015):

en vez del paisaje
tener que mirar
a cada rato
el camino
de ripio al pasar
los cambios
ejercer desquiciadas
posturas (74-5).

En el fragmento citado, la descripción paulatinamente es reemplazada por simples expresiones despojadas de adjetivos. Este poemario está compuesto con varios y variados adverbios, en este poema en particular, vemos que está la expresión "a cada rato", la que puede homologarse a la sensación de repetición ocasionada al transitar por un camino de ripio por el que pasa el sujeto poético, traspasando su mirada y voz al escribir los versos que acá leemos. Así aparece la representación de una latencia y una duración breve del paisaje, determinada por la velocidad que adquiere la mirada para quien viaja en automóvil, lejos de la contemplación de la poesía romántica, los nocturnos o el deambular sin rumbo del wanderer. El tono del texto ya nos entrega a los lectores la imposición de esta mirada: “en vez del paisaje / tener que mirar". De esta manera, dicho cambio del paisaje en la mirada de quien lo ve -señalado por Masiello en relación con la poesía- se hace evidente con este poema en donde todo pareciera pasar de largo, incluso los versos en el camino que realizamos con la rápida lectura, 
como si se imitase con eso el recorrido veloz de la no contemplación para el sujeto poético. Según Gustavo Guerrero, en su reciente artículo "Materialismo, realismo y prosaísmo en la joven poesía latinoamericana de los años noventa": "Los antiguos pactos entre lenguaje y mundo material se han roto [...] Por el contrario, el silencio de las cosas es ahora el asunto común que les permite hacer un balance de sus poderes perdidos ante un mundo que se ha vuelto indiferente, distante y ajeno" (400). Guerrero, parafraseando a Rancière, sostiene que el poema -de los noventa en adelante-asiste a un colapso final del régimen de representación de la literatura y el arte (403). Sin embargo, agregaríamos que particularmente en la sección "De la poesía del futuro a la poesía del pasado" de La palabra muda, Rancière sí otorga a la poeticidad la capacidad de ser contra toda indiferencia: "la poesía es un lenguaje caracterizado por su motivación, por su semejanza con lo que dice [...] el poeta es aquel que no puede expresar nada distinto de lo que expresa y que no puede expresarlo en ningún otro modo del lenguaje" (76). Más adelante, define este lugar de lo poético no solamente como representación sino como superficie que exhibe: "La 'poesía' no es nada más que la disolución continua de la representación, nada más que el acto de exhibirse a sí misma, de exhibir, en detrimento de todo objeto, su sola intención vacía" (93).

Estos poemas pueden ser respuesta o pregunta sobre esta relación entre sujeto poético, mirada y transeúnte, que expone ese mundo natural y material en discordancia, afectado por el régimen social y económico. Estos poemas son imágenes reales en cuanto muestran desde el lenguaje aquel paisaje por donde deambula el sujeto poético. Ahí estaría esa realidad, traspasada por amarillo crepúsculo-como un atardecer en Santiago contaminado- o un puerto del Pacífico, Valparaíso, oxidado como una calamina. Materiales y sustancias que adquieren significaciones más allá de sus descripciones visuales o sustanciales. Como figuras poéticas serían sinécdoques, en las cuales los entornos contemporáneos son mediados por miradas, medios, estableciendo el lugar del sujeto como el de un observador crítico. Estos paisajes no son solo materiales del poema o del lenguaje, sino que hablan a través de este del paso del tiempo, de la industrialización, de la presencia de materialidades otras como los colorantes artificiales o el óxido producido por la intemperie. Esta contemporánea habitabilidad que se presenta precaria está siendo tocada por los colores de la industrialización por un lado, y de la pobreza por otro, caras de la modernidad y revés de ella y la vida contemporánea. Así, los sujetos poéticos son operadores que deambulan entre escombros y residuos. Tocan esos paisajes y los encuadran como pinturas postales postnaturales contempladas, sin la intención de lo sublime, sino que entregándole valor -como diría Rancière- a la potencialidad del fragmento. Es el artista, en este caso el poeta, quien dará una forma a aquello informe, despojado de la historicidad. Solo es la materialidad la que otorga esa noción de paso del tiempo, material poetizable para crear y dar lugar a una nueva geografía poética. Y así afirmar junto con el sujeto poético, como señala Anwandter, que ese paisaje también devela algo íntimo, va junto a nuestros afectos: "se echa un trozo del paisaje / que se aleja al bolsillo" (221). 


\section{Referencias}

Amaro, Lorena. "El silencio del óxido. Reseña Gladys González". 60 Watts, Iluminando Lecturas. <http://60watts.cl/2014/04/resena-gladys-gonzalez $>$. Fecha de ingreso: 10 octubre de 2015 . Web.

Andermann, Jens. “Paisaje: imagen, entorno, ensamble”. Orbis Tertius XIII/14 (2008). 1-7. Impreso.

---. "Entre la topografía y la iconografía. Mapas y nación 1880". La ciencia en la Argentina entre siglos: Textos, contextos e instituciones. Ed. Marcelo Montserrat. Buenos Aires: Manantial, 2000. 101-125. Impreso.

Anwandter, Andrés. Amarillo Crepúsculo. 2000. 101-125. Impreso Adverbios terminados en mente. Santiago: Garceta ediciones, 2015. Impreso.

Augé, Marc. “Turismo y viaje, paisaje y escritura”. El tiempo en ruinas. Barcelona: Gedisa, 2003. 59-95. Impreso.

Ayala, Matías. "Amarillo crepúsculo. De la lírica a la política”. Revista Intemperie. $<$ www.revistaintemperie.cl/index.php/2012/03/21/amarillocrespusculo-andresanwandter/>. Fecha de ingreso: 08 de octubre de 2015. Web.

Bellessi, Diana. Lo propio y lo ajeno. Santiago: Lom, 2006. Impreso.

Collot, Michel. "Approches Geópoetiques”, “Approches Géographiques”. Pour une géographie littéraire. Paris: Editions Corti, 2014. 59-130. Impreso.

. Paysage et poésie. Paris: Corti, 2005. Impreso.

Comolli, Jean Louis. "Abrir la ventana”. Cine contra espectáculo seguido de Técnica e ideología (1971-1972). Buenos Aires: Manantial, 2010. 21-61. Impreso.

Cool, Diana, Samantha Frost, eds. New Materialisms: Ontology, Agency, and Politics. Durham: Duke University Press, 2010. Impreso.

Descola, Philippe. "La gran división. La autonomía del paisaje”. Más allá de naturaleza y cultura. Buenos Aires: Amorrortu, 2012. 102-110. Impreso .

Fitter, Chris. "Toward a Theory of 'Landscape' and Landscape Perception". Poetry, Space, Landscape. Toward a New Theory. Cambridge: Cambridge University Press, 1995. 1-24. Impreso.

González, Gladys. Calamina. Santiago: La Calabaza del Diablo, 2014. Impreso.

Guerrero, Gustavo. "Materialismo, realismo y prosaísmo en la joven poesía latinoamericana de los años noventa". Cuadernos de Literatura 40 (2016): 394-410. Impreso.

Hoyos, Héctor. "La cultura material en las literaturas y culturas iberoamericanas de hoy”. Cuadernos de Literatura 40 (2016). 254-261. Impreso.

Kamenszain, Tamara. "Juan L. Ortiz: La lírica entre comillas”, El texto silencioso. Historias de amor (y otros ensayos sobre poesía). Buenos Aires: Paidós, 2000. 181-187. Impreso.

Kirkpatrick, Gwen. "Poetry in Ruins: Scenes of Destruction or Renewal?”. Poetics of Hispanism. Ed. Cathy L. Jrade \& Christina Karageorgou-Bastea. Frankfurt: Iberoamericana-Vervuert, 2012. 163-178. Impreso. 
"Landscape Poem". Greene, Roland et al. The Princeton Encyclopedia of Poetry and Poetics. Princeton: Princeton University Press, 2012. Impreso.

Masiello, Francine. "La naturaleza del poema (de Mistral a Padeletti)". El cuerpo de la voz (poesía, ética y cultura). Rosario: Beatriz Viterbo, 2013. 95-124. Impreso.

---. Lenguaje e ideología. Las escuelas argentinas de vanguardia. Buenos Aires: Hachette, 1986. Impreso.

Milani, Raffaele. El arte del paisaje. Madrid: Biblioteca Nueva, 2008. Impreso.

Mitchell, W.J.T. Landscape and Power. Chicago: University of Chicago Press, 2002. Impreso.

Padilla, José Ignacio. El terreno en disputa es el lenguaje. Madrid: Iberoamericana Vervuert, 2014. Impreso.

Puppo, María Lucía. Entre el vértigo y la ruina. Poesía contemporánea y experiencia urbana. Buenos Aires: Biblos, 2014. Impreso.

Rancière, Jacques. "De la poesía del futuro a la poesía del pasado". La palabra muda. Ensayos sobre las contradicciones de la literatura. Trad. Cecilia González. Buenos Aires: Eterna Cadencia, 2009. 75-94. Impreso.

Sepúlveda, Magda. Ciudad quiltra. Poesía chilena (1973-2013). Santiago: Cuarto propio, 2013. Impreso.

Stewart, Susan. "Out of the Darkness: Nocturnes". Poetry and the Fate of the Senses. Chicago: The University of Chicago Press, 2002. 255-280. Impreso.

Subercaseaux, Benjamin. Chile o una loca geografía. 1940. Santiago: Universitaria, 2011. Impreso.

Vendler, Helen. "The Waste Land. Fragments and Montage". The Ocean, the Bird and the Scholar. Essays on Poets and Poetry. Cambridge, MA: Harvard University Press, 2015. 79-92. Impreso.

Recibido: 19 diciembre 2016 Aceptado: 7 julio 2017 